\title{
A Stable International Monetary System Emerges: Inflation Targeting is Bretton Woods, Reversed Andrew K. Rose*
}

\author{
Revised as of: November 15, 2006
}

Comments Welcome!

\begin{abstract}
A stable international monetary system has emerged since the early 1990s. A large number of industrial and a growing number of developing countries now have domestic inflation targets administered by independent and transparent central banks. These countries place few restrictions on capital mobility and allow their exchange rates to float. The domestic focus of monetary policy in these countries does not have any obvious international cost. Inflation targeters have lower exchange rate volatility and less frequent "sudden stops" of capital flows than similar countries that do not target inflation. Inflation targeting countries also do not have current accounts or international reserves that look different from other countries. This system was not planned and does not rely on international coordination. There is no role for a center country, the IMF, or gold. It is durable; in contrast to other monetary regimes, no country has been forced to abandon an inflation-targeting regime. Succinctly, it is the diametric opposite of the post-war system; Bretton Woods, reversed.
\end{abstract}

Keywords: fixed, financial, exchange, rate, capital, controls, durable, regime.

JEL Classification Numbers: F02, F33

\author{
Andrew K. Rose \\ Haas School of Business \\ University of California \\ Berkeley, CA USA 94720-1900 \\ Tel: (510) 642-6609 \\ Fax: (510) 642-4700 \\ E-mail: arose@haas.berkeley.edu
}

* B.T. Rocca Jr. Professor of International Trade, NBER research associate and CEPR research fellow. This research was conducted in part while I visited INSEAD, the Monetary Authority of Singapore and the National University of Singapore, whom I thank for hospitality. For comments, I thank: Joshua Aizenman, Michael Dooley, Sebastian Edwards, Barry Eichengreen, Pierre-Olivier Gourinchas, Harald Hau, Brian Pinto, Mark Spiegel, Janet Yellen, and conference participants at UCSC. A current (PDF) version of this paper, sample output, and the data sets used in the paper are available at http://faculty.haas.berkeley.edu/arose. 


\section{Motivation and Introduction}

All countries choose their monetary policy. Collectively, the interaction of these policies constitutes the international monetary system. For instance, during the "Bretton Woods" regime after WWII, countries fixed their exchange rates to the American dollar. A fixed exchange rate is a well-defined monetary policy that is still used by a number of countries. In the presence of capital mobility, it subordinates monetary policy to the objective of exchange rate stability at the expense of other domestic interests. Because of this conflict, most fixed exchange rates do not stayed fixed for long. But when countries float their exchange rates, they have to choose another monetary regime; floating is not a coherent monetary policy. Some countries have tried to pursue money growth targets, often without success. Others have hybrid strategies involving multiple or moving targets; some countries do not even have clearly-defined monetary policies.

Fourteen of the thirty OECD countries currently have a monetary policy that explicitly targets inflation. These countries have a combined population exceeding 430 million, and produce over an eighth of global output, so inflation targeting is an important monetary policy. But even these impressive numbers understate the importance of inflation targeting (hereafter “IT"). Twelve OECD countries are in EMU, which is almost a formal inflation targeter (Wyplosz, 2006), and may become one soon; another pair (Denmark and the Slovak Republic) are waiting to join EMU. ${ }^{1}$ The United States has been an implicit IT country for years (Goodfriend, 2003), and may become an explicit one soon. There is speculation that Japan may adopt IT when its deflationary days are definitively over. So the entire OECD may soon be using the same monetary strategy.

But inflation targeting is not simply a policy of rich countries. As of June 2006, ten developing countries with 750 million people have also adopted IT. Altogether, countries that 
formally target inflation currently constitute over a quarter of the global economy. And IT is not only important but likely to grow in significance as the remaining OECD and more developing countries adopt it.

This paper examines the implications of this widespread policy for the international monetary system.

\section{Targeting Inflation, Floating Exchange Rates}

Mishkin (2004) lists five components to an inflation targeting regime:

1. The public announcement of medium-term numerical targets for inflation,

2. An institutional commitment to price stability as the primary goal of monetary policy,

3. An information-inclusive strategy to set policy instruments,

4. Increased transparency of the monetary policy strategy, and

5. Increased accountability of central bank for attaining its inflation objectives.

While inflation targeting has been defined in different ways, most are similar. Table A1 lists IT countries, along with the dates that the IT regime began. It is not always clear precisely when an IT regime began, and scholars sometimes disagree about these dates. For instance, Mishkin and Schmidt-Hebbel (2001) date the start of Australia's IT regime to September 1994 whereas the Reserve Bank of Australia dates it to March 1993. ${ }^{2}$ Accordingly, I tabulate a default date that represents my best judgment as to when IT began, along with a conservative date. These are typically close together. ${ }^{3}$

An inflation targeting regime usually entails a floating exchange rate (Taylor, 2001). Insofar as inflation targeting countries use a formal intermediate target for monetary policy, it is the inflation forecast, rather than, e.g., the exchange rate or money growth rate (Bernanke and Mishkin, 1997). Most IT countries let their exchange rates float quite freely. A typical statement comes from the Bank of Israel, which states that "the Bank of Israel has adopted a 
strategy of no direct intervention in the determination of the exchange rate. This means allowing the exchange rate to fluctuate continuously in response to financial and economic changes ..."4 The Norwegian central bank has not intervened since January 1999, the Canadian since September 1998, the Israeli since June 1997, and the British have intervened only once since September 1997. ${ }^{5}$ New Zealand has not intervened in the foreign exchange market in over twenty years! ${ }^{6}$ There are exceptions of course; the Reserve Bank of Australia intervened in the 1990s, the developing countries sometimes intervene, and a few have even maintained exchange rate targets for a while along with their inflation target. But the trend is clearly towards flexible rates; when countries do intervene, the IT countries now do so in order to hit their inflation targets, not to maintain fixed exchange rates. ${ }^{7}$

So the international monetary system seems likely to be increasingly dominated by IT countries with floating exchange rates. Despite the relatively youth of this system, some of its properties have been already studied from a theoretical viewpoint; see e.g., Benigno and Benigno (2005, 2006) and Obstfeld and Rogoff (2002). The characteristics of IT countries have been studied empirically, and much is now known about monetary policy under IT; see, e.g., Ball and Sheridan (2003), Bernanke et al (1999), IMF (2005), Levin et al (2004), and Siklos (1999). However, the focus of empirical work in IT is almost always on domestic aspects of IT, such as the level, volatility, or persistence of inflation or output. There has been little positive analysis of the international effects of IT. Accordingly, the focus of this paper is empirical and international, rather than normative or domestic.

\section{Inflation Targeting: A Durable Monetary Regime}


Inflation targeting has proven to be quite durable. Twenty-three countries adopted inflation targets by the end of 2004 (another four have joined in the eighteen months following). Only two of those - Finland and Spain - have abandoned IT. Both left to join EMU in 1999, neither under economic duress (and the ECB maintains an inflation target). This stands in stark contrast to alternative monetary regimes experienced since WWII, which have been plagued by crisis and failure, and accordingly transient. Fixed exchange rate regimes do not stay fixed forever! Other monetary strategies - such as money growth targets, multiple targets, or hybrid strategies - also tend to be short lived, unsuccessful, or both.

Describing IT as a durable policy may seem like a bold assertion. After all, New Zealand adopted the first IT strategy only in 1990. As of June 2006 we have at most sixteen years of experience with inflation targeting. This is especially true of developing countries. Chile started to target inflation in 1991, but many developing countries that have been targeting inflation have done so for only a short while.

Still, looking back over the last century, sixteen years turns out to be a long time for a monetary regime. Writing before the currency crises of the late 1990s, Obstfeld and Rogoff (1995) forcefully pointed out how very transient modern fixed exchange rate regimes seem to be. ${ }^{8}$ Even the Bretton Woods regime of capital controls and fixed but adjustable pegged exchange rates lasted less than thirteen years, from January 1959 (when European currencies became convertible for current account transactions) through the crisis of August 1971. ${ }^{9}$ (Even this period was far from smooth; Germany and the Netherlands revalued in 1961, the UK and France devalued in 1967 and 1969 respectively, while Germany floated and then revalued in 1969. ${ }^{10}$ ) And most regimes that target money growth have not survived even that long. ${ }^{11}$ 


\section{How Long do Exchange Rate Regimes Last?}

It is not possible to sensibly estimate the reasons why countries crash out of IT regimes, since none ever has. ${ }^{12}$ Still, one can compare the durability of IT with that of monetary regimes chosen by other (non-IT) countries during the same period of time. Accordingly, I form a “control group" of country x year observations for the period since IT began in early 1990 through the end of most usable data in 2004. To ensure that the members of the control group can be reasonably compared with the IT countries, I restrict my attention to non-IT countries with a) real GDP per capita at least as high as those of the poorest IT country in 2000, and b) population at least as big as those of the smallest IT country. ${ }^{13}$ From the universe of all countries with their own money, I form a set of 42 control group countries. ${ }^{14}$ Since Iceland (the smallest IT country) is something of a size outlier, as a sensitivity check I also exclude countries smaller than New Zealand (the second-smallest IT country) but larger than Iceland. ${ }^{15}$ The members of the control group are tabulated in Table A2; "small" countries (defined as those whose 2000 population lay between Iceland and New Zealand) are marked. ${ }^{16}$

In Table A2 I also provide the most recent available IMF information on the monetary framework, as well as the number of changes in exchange rate regimes experienced by each of the control group countries. ${ }^{17}$ I use two different exchange rate regime classifications. The first is the well-known data set of Levy-Yeyati and Sturzenegger (2003), hereafter "LYS", who use a combination of exchange rate behavior and central bank intervention to create a five-way classification of regimes (float, dirty float, crawling peg, fix, and inconclusive). The second data set is also well-known, and was created by Reinhart and Rogoff (2004), hereafter "RR”, by comparing exchange rate behavior over time for official and market rates to create a 14-way 
classification of exchange regimes. ${ }^{18}$ The annual LYS data are available from 1990 through the end of 2004, while the monthly RR data extend only through $2001 .^{19}$

There are clearly issues associated with these measures of monetary policy regimes. First, the samples considered by LYS and RR do not coincide. ${ }^{20}$ Second, there are differences between the classifications thrown out by the two systems. For instance LYS count 7 switches of exchange rate regime for Belarus between 1990 and 2004; in contrast, RR have none between 1990 and 2001. (The discrepancy may be more imagined than real, since RR classify Belarus as "freely falling" throughout, thus essentially agreeing with LYS that Belarus conducted unstable monetary policy continuously). Most significantly, it is possible that switches in the monetary regime need not be reflected in either the RR or LYS classifications. One would like to have measures of monetary policy regimes rather than exchange rate regimes; to repeat, a fixed exchange rate provides a nominal anchor for monetary policy, but a float does not. Thus in both data sets, a country that maintains a floating exchange rate and moves into or out of (say) a money growth target may show no change in its exchange rate regime. ${ }^{21}$ So the RR and LYS are noisy measures of switches in monetary regimes, and are likely to understate the actual amount change in a country's monetary regime. ${ }^{22}$

Still, even a naïve look at Table A2 shows just how unstable most monetary policies have been. Many of the 42 countries in the control group have experienced numerous changes in the exchange rate regime. For instance, Jamaica switched regimes eleven times in fifteen years according to the LYS method, and five in the twelve available years of RR data. Only five countries experienced no changes under either classification. Of these, Morocco targets M1 growth, and maintains an exchange rate peg with many controls against a secret multilateral basket, while Syria maintains an exchange rate peg but with many controls and multiple 
exchange rates. So there are only three relevant countries with monetary regimes as durable as inflation targeting. One is Hong Kong's successful currency board. The IMF describes the other two - Japan and the United States - as having "no explicitly stated nominal anchor, but monitoring various indicators in conducting monetary policy."23

It is possible to look at the data on exchange rate regime switches more comprehensively and rigorously. I use standard statistical techniques (see e.g., Gopinath and Rigobon, 2006) and define three measures of regime persistence as:

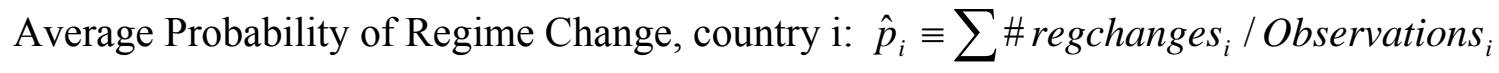
Average time in Regime, country i: $\widetilde{t}_{i} \equiv \sum$ Timeinregime $_{i} /$ regimes $_{i}$ Spell-weighted Avg time in Regime, country i: $\hat{t}_{i} \equiv \sum$ (Timeinregime $\left._{i}\right)^{2} /$ Observations $_{i}$ where: \#regchanges $s_{i}$ is the number of regime changes for country $i$, Observations $_{i}$ is the number of (country*period) observations, Timeinregime is the time spent inside in a regime, and regimes is the total number of regimes.

The average probability of regime change may be uninteresting if a small number of countries dominates the sample. The second measure uses each regime as a spell of time, and is simply the inverse of the probability of change. The third measure corrects the second one for bias by weighting observations by the length of the regime; Gopinath and Rigobon provide more details and an example.

I construct my measures for each country in the control group, and tabulate in Table 1 simple averages computed across countries. Levy-Yeyati and Sturzenegger (2003) present two (similar) exchange rate regime classifications; one uses three "buckets" while the other uses five. 
I use both, as well as the RR classification. To ensure robustness, I also calculate the statistics after excluding the small countries identified in Table A1. Thus there are six (= three regime classifications $\mathrm{x}$ with/without small countries) different estimates tabulated for each statistic.

The estimates of Table 1 give a strong impression that exchange rate regimes for the control group countries have not lasted long. The exact estimates vary a little depending on whether one uses the LYS or RR classification of exchange rate regimes. The RR scheme shows a lower probability of regime change, and a longer average time between regime switches. Still, the most striking finding is how transient exchange rate regimes are. The probability of a regime changing within a year is over a quarter if ones uses the LYS scheme, so that the average regime lasts three years or less. Using the RR classification increases durability some, as does weighting the average time spent in a regime. But overall, exchange rate regimes seem to be ephemeral phenomena. Nothing much depends on whether one uses the 3- or 5-bucket LYS measure, or whether one includes or excludes small countries.

I supplement the three statistical measures presented in Table 1 with survivorship data in Table 2. I tabulate the probability of exchange rate regimes surviving for different periods of time, in particular through two, four, six and eight years. To check the sensitivity of my results, I again use all three exchange rate regime classifications, and both include and exclude small countries. Since there are different ways to treat the interaction between countries and exchange rate regimes, I produce three sets of results. In the top panel, I treat countries as having countryspecific characteristics since countries may have different probabilities of having exchange rate regimes survive. Alternatively, one can treat each exchange rate regime as an independent observation, as I do in the middle panel. Finally, one can consider only the regime that a country began the sample with, and determine the probability of that initial regime surviving. 
No matter how you chop up the data, the impression one gets from Table 2 echoes that of Table 1; exchange rate regimes tend to be fleeting. The default results of Table 2a indicate that the probability of a regime surviving even eight years is below .3; for the 5-regime LYS scheme, it is below .1. The exact survivorship rates vary somewhat, but essentially all are low even six or eight years out. This implies that the data we have on the duration of existing IT countries is starting to be of meaningful duration. Nine IT regimes have already survived eight years; if inflation targeting was comparable in durability to an exchange rate regime, this would be

extremely unlikely. ${ }^{24}$ I conclude that IT has already proven to be a durable monetary regime, in stark contrast to exchange rate regimes. ${ }^{25}$

\section{Bretton Woods, Reversed}

A number of IT countries are currently in an apparently durable monetary regime; this is the most striking contrast with previous international monetary systems such as the Bretton Woods system. But there are many others. In fact, there are so many points of comparisons between the features of the Bretton Woods system and the behavior of the inflation targeters that I have collected them together in Table 3.

Most of the differences are straightforward between the systems are straightforward. Mundell's celebrated "Incompatible Trinity" states that fixed exchange rates, free capital flows and a domestic focus for monetary policy are desirable goals that are mutually exclusive. Most IT countries have liberalized capital markets and relinquished control over their exchange rates, the exact opposite of the Bretton Woods system. ${ }^{26}$ Since the IT countries float, there is typically no important role for public capital flows any more; speculative activity on the foreign exchange markets revolves around floaters, not speculators trying to attack a country's fixed rate. And the 
increased volume of private capital flows has allowed the system to handle large sustained current account imbalances, which are proportionately larger now than during the Bretton Woods regime.

The current system seems to be delivering different (often better) economic outcomes than the Bretton Woods regime. But it is also interesting to trace the history of the system. The Bretton Woods system was deliberately planned, the outcome of a long series of negotiations between eminent economists representing the interests of critical countries. "Bretton Woods" itself is the name of the resort town in New Hampshire where the conference delegates signed the agreements for the International Monetary Fund, the World Bank and the ITO/GATT in July 1944.

The deliberate design and construction of the Bretton Woods system can be contrasted with the evolution of the current system. Countries that adopt IT do not agree to join an internationally recognized monetary system and do not accept commonly accepted "rules of the game" either implicitly or explicitly. Rather, the system has grown in a more Darwinian style, simply because of its manifest success. International cooperation is simply not a key part of the current international monetary system. This is another difference with the Bretton Woods system which required massive international cooperation to function. ${ }^{27}$ Accordingly, many of the key institutions of the Bretton Woods system are now essentially irrelevant. The International Monetary Fund has evolved into a crisis-manager for developing countries (often those suffering speculative attacks on their fixed exchange rate regimes), and plays no real role in the new system. There is no special role for a center or anchor country like the United States - that is, no "N/N-1 problem." Gold is irrelevant (as is the SDR). Developing countries are participating more quickly and fully in the system than they did under Bretton Woods. The key 
players are central banks; these are now more independent, accountable and transparent than under Bretton Woods.

One final point is of interest. Serious objections had been made to the Bretton Woods system by well-known economists long before its demise. Robert Triffin observed as early as 1947 that the system had a tendency to meet the demand for reserves through the growth of foreign dollar balances, making it dynamically unstable. Milton Friedman famously made the case for floating exchange rates in 1950, a case emphatically echoed by Harry Johnson in 1969. By way of contrast, there is a much greater alignment of IT with academic thought. Indeed, much of the case for inflation targeting was made by distinguished academics including Ben Bernanke, Rick Mishkin, and Lars Svensson.

\section{Exchange Rate Volatility}

Inflation targeting requires exchange rate flexibility. But do countries with IT experience systematically higher exchange rate volatility in practice? Does the domestic focus of monetary policy under IT impose a "cost" on the country in the form of substantially higher exchange rate volatility? Many countries seem to have a "fear of floating" (especially in developing countries); when they adopt IT, are their fears justified? Or does the presence of a durable monetary framework eliminate policy shocks that cause exchange rate volatility? I now attempt to answer such questions by comparing exchange rate volatility between the IT and control group countries. $^{28}$

I use multilateral (effective) exchange rates for both IT and control group countries from the International Monetary Fund's International Financial Statistics data set. I use both nominal (IFS line "neu" for industrial countries, "nec" for developing countries) and real exchange rate 
measures; the latter are based on relative CPIs (IFS line "rec"). The series are available monthly from 1990 through December 2005. Data on nominal effective exchange rates are available for 45 IT and control group countries, while real rates are available for 42 of them (the three missing are Hong Kong, SAR China; the Dominican Republic, and Lebanon).

To measure volatility, I take natural logarithms of effective exchange rates, and then estimate the standard deviation of a country's log effective exchange rate over an interval of time. The appropriate period for the data is not obvious, so I use three alternatives to split the data into sensible mutually exclusive and jointly exhaustive periods. First, for each country I estimate four standard deviations, one over each four-year long period between January 1990 and December 2005. (Thus the first standard deviation for Australia is estimated using data from 1990m1 through 1993m12; the second one from 1994m1 through $1997 \mathrm{~m} 12$ and so forth.) Second, for each country I estimate two standard deviations, one from each of the two eight-year periods. Finally, for each country I estimate one standard deviation over the entire sixteen year period. Thus, at (say) the four-year horizon I have observations from a number of different IT and control-group countries, each contributing a maximum of four observations over time. ${ }^{29}$ I use all available data for the control group countries, and the IT regime observations for the IT countries. $^{30}$

I then regress exchange rate volatility on a binary dummy variable which is one for countries that use IT, and zero otherwise. I use OLS and also include an intercept, time-specific fixed effects, and a set of control variables. That is, I estimate:

$$
\operatorname{Vol}(e e r)_{i t}=\beta I T_{i t}+\alpha+\Sigma_{t} \gamma_{t} T_{t}+\Sigma_{j} \delta_{j} X_{j i t}+\varepsilon_{i t}
$$


where: $\operatorname{Vol}(\mathrm{eer})_{\mathrm{it}}$ is the volatility of the effective exchange rate for country i over period $\mathrm{t}, \mathrm{IT}_{\mathrm{it}}$ is a dummy variable that is one if $i$ is an inflation targeter over period $t$ and zero otherwise, $T_{t}$ is a period-specific fixed effect, $\mathrm{X}_{\mathrm{jit}}$ is a set of controls, $\varepsilon$ is a well-behaved disturbance term, and $\alpha$, $\gamma$, and $\delta$ are nuisance parameters. The regressors that I include as controls are the average values of: 1) the current account (expressed as a percentage of GDP);2) the natural logarithm of openness (exports plus imports, again as a percentage of GDP); 3) log population; and 4) log PPP-adjusted real GDP per capita. The data for the control variables are all taken from the World Bank's World Development Indicators. ${ }^{31}$

Table 4 reports coefficient estimates for this dummy variable, along with standard errors in parentheses; estimates that are significantly different from zero at the $.05(.01)$ level are marked by one (two) asterisk(s). A negative coefficient indicates that exchange rate volatility is lower under IT. There are six columns of results. Three use the nominal exchange rate to construct the dependent variable at the 4- 8- and 16-year intervals; the other three use the real exchange rate (at the same intervals).

A caveat. Since I ignore how countries choose their monetary regime, I am implicitly ignoring potential simultaneity and selection issues. Since not all countries have adopted it, inflation targeting is clearly not a panacea. ${ }^{32}$ But as no IT regimes have yet failed, we cannot seriously address the reasons why they might fail with quantitative tools. More generally, we do not currently have a good understanding of how countries choose their monetary regime in practice. This is a fruitful area for future research.

The default estimates are presented in the top row of the table. All six coefficients are negative, though only one is significantly different from zero (for nominal exchange rate volatility using a single cross-section of volatility calculated over all sixteen years of data). Still, 
the striking feature is that the coefficients are negative at all. This implies that exchange rate volatility (both real and nominal) is actually lower for IT countries than for the control group, some of whom maintain fixed exchange rate regimes!

An additional twelve rows present a variety of robustness checks. The first few change the default specification by successively dropping: 1) the time-specific fixed effects; 2) the four controls; and 3) just the population and current account controls. I also try a specification where the level rather than the log of openness is used. I then handle outliers in two different ways. First, I drop all observations where the residual is large (more than 1.5 standard deviations from the mean). Second, I use a quantile (least absolute deviations) estimator. The next three experiments change the sample by dropping: 1) small countries, 2) poor countries (those with real GDP per capita below \$5000), and 3) the four countries that switched to IT after 2004. I then weight observations by log real GDP. The final two checks change the regressand so as to measure volatility in different ways. Since the nominal effective exchange rate could be nonstationary, I calculate my standard deviations from the first-difference of natural logarithms. As an additional robustness check, I then replace the standard deviation of the log of the nominal effective exchange rate with the mean absolute first-difference of the log exchange rate. None of this sensitivity analysis undermines the initial finding. Of the 64 coefficients presented, only five are positive, none significantly so. Seventeen of the 64 coefficients are significantly negative at the .05 level, eight of these at the .01 level.

To summarize: exchange rate volatility for IT countries is typically (though often insignificantly) lower for IT countries than for others. That is, the domestic focus of inflation targeting does not seem to come at the expense of higher exchange rate volatility. 


\section{5. "Sudden Stops" of Capital Inflows}

There has been much discussion in the literature recently concerning "sudden stops" of international capital. These dramatic shifts in capital flows are often associated with considerable economic distress, and have thus been examined extensively; Calvo, Izquierdo and Talvi (2006) provide a recent treatment. Accordingly, I now briefly examine whether IT countries have the same propensity to be affected by sudden stops as non-IT countries. ${ }^{33}$

Since there is no universally-accepted definition of sudden stops, I examine a number of definitions. In particular, I use five sets of sudden stop dates - all that I could find - from Calvo, Izquierdo, and Mejía (2004), Calvo, Izquierdo and Talvi (2006), Eichengreen, Gupta and Mody (2006), Frankel and Cavallo (2004), and Frankel and Wei (2004). These dates differ in a number of respects, including the countries and periods covered, the method of identifying sudden stops, and so forth.

Table 5a presents a tabulation of the 294 observations in my sample that overlap with Calvo, Izquierdo, and Mejía (2004). Each (country x year) observation can be classified by whether it is a) a sudden stop or not (in which case it is labeled "tranquil"); and b) its monetary regime: control observation (for non-IT countries); IT observation; or a pre-IT observation (for the observations before the country changed to IT). The other definitions of sudden stops are presented in panels $5 \mathrm{~b}-5 \mathrm{e}$.

It is apparent from all five panels that it is rare for an IT country to experience a sudden stop. For instance, Table 5a indicates that the Calvo, Izquierdo, and Mejía (2004) definition delivers only one sudden stop for an IT country out of the 94 possible observations. However, eight of the 72 possible control-group observations are sudden stops. Further, in the 128 observations available before the IT countries switched to inflation targeting, they experienced 
nine sudden stops. For all five definitions of sudden stops, IT countries were less likely to experience sudden stops than they were either a) before they switched to inflation targeting, or b) compared with the control-group countries with other monetary regimes.

That said, sudden stops are rare events, so that these differences are usually statistically insignificant; only the Calvo, Izquierdo, and Mejía (2004) register at conventional levels. The last panel of Table 5 presents formal t-tests for equality of frequency of sudden stops, along with the associated p-values. The first row tests the hypothesis of equal frequency of sudden stops between control-group and IT countries; a positive t-statistic indicates that control group observations were more likely to experience sudden stops than IT countries. The second row compares pre- and post-IT observations for countries that adopted IT between 1990 and 2004; a negative value indicates that the frequency of sudden stops fell after the adoption of inflation targeting. IT countries experienced fewer sudden stops than either the period before they adopted IT, or than comparable countries with other monetary regimes, but only two of the ten differences are statistically significant.

Succinctly, countries that switch to inflation targeting experience a drop in the frequency of sudden stops. Sudden stops are also less common in inflation targeters than they are in control group countries. These differences are usually statistically insignificant, which seems unsurprising given the rarity of sudden stops. Still, they support the conjecture that the financial crises that plagued the world in the 1990s may soon be a thing of the past.

\section{Reserves and Current Accounts}

There is much interest these days in reserve accumulation and current account imbalances, especially for East Asian economies. Accordingly it is interesting to examine the 
behavior of international reserves and current account imbalances, especially to compare the IT and control group countries.

I use two conventional measures of international reserves. The more traditional one compares international reserves with trade flows by measuring reserves in months of imports. The newer convention is to measure broad money (M2) as a ratio to reserves. The current account is measured as a percentage of GDP, positive figures indicating surpluses. The data are annual WDI series, available from 1990 through 2004.

To smooth out the data, I construct (country-specific) averages over time for the three variables of interest (M2/reserves, reserves in import months, and the current account as a percentage of GDP). I follow the strategy I used for exchange rate volatility, and compute my averages over each four-year periods (1990-93, 1994-97, 1998-2001, and 2002-04), eight-year periods (1990-97, 1998-2004), and the whole sample (1990-2004). For each sample, I then tabulate the averages for IT countries, and for the control group countries. These are presented in the top rows of Table 6; the three panels correspond to the three variables of interest.

Average values for reserves and current accounts for IT countries are generally close to those for the control group. Reserves look smaller for the IT countries compared with the control group, but only really for the mid-1990s and when normalized by money. Reserves look similar between IT and other countries for other samples, or when normalized by trade. The differences are never statistically significant; simple t-tests cannot reject the hypothesis of equal means at standard confidence levels. Similarly, current account imbalances also look similar across IT and control group countries.

The average values mask considerable dispersion across countries. For instance, even if one restricts attention to the control group during the 1990-93 period, Jordan averaged a current 
account deficit of $10.5 \%$ of GDP, while Singapore maintained a mean current account surplus of 9.7\%. Even if the average values are similar across IT and control group countries, other parts of the distribution may be different. To test this hypothesis rigorously, I conduct non-parametric Kolmogorov-Smirnov tests for equality of distributions between the IT and control group countries. The p-values for the hypothesis of equal distributions are tabulated in Table 6 . With the exception noted above (M2/Reserves in the mid-1990s), the hypothesis of equal distribution cannot be rejected at conventional levels.

To summarize, reserves and current account imbalances for inflation targeters look similar to those of the control group. Again, the domestic focus of monetary policy under IT does not have significant consequences for key features of the international monetary landscape.

\section{Conclusion}

Countries have a limited number of choices for their monetary strategy. Historically a large but declining number of countries have fixed their exchange rates. A number of countries have experimented with the idea of setting money growth targets. Some countries pursue hybrid or ill-defined strategies. And an increasing number of countries grant their central banks independence to pursue a domestic inflation target.

Inflation targeters let their exchange rates float, usually without controls on capital flows and often without intervention. Because the goal of monetary policy is aligned with national interests, inflation targeting seems remarkably durable, especially by way of contrast with the alternatives. It is striking that no country has ever been forced to abandon an inflation-targeting regime. But the domestic focus of inflation targeting does not seem to have observable international costs. Countries that target inflation experience lower exchange rate volatility and 
fewer "sudden stops" of capital flows than their counterparts; nor do they have different current accounts imbalances, or reserve levels.

As a result of its manifest success, inflation targeting has continued to spread; it now includes a number of developing countries as well as a large chunk of the OECD. Indeed the spread of this monetary strategy has been remarkably fast in the conservative world of monetary policy. The system of domestically-oriented monetary policy with floating exchange rates and capital mobility was not formally planned. It does not have a central role for the United States, gold, or the International Monetary Fund. In short, it is the diametric opposite of the postwar system; Bretton Woods, reversed.

Sustainability is currently the biggest policy issue in international monetary affairs. There is much heated discussion over global imbalances and the Chinese-American exchange rate; is there a "revived" Bretton Woods system? In the midst of this debate, we should not lose sight of the resilience and stability of the emerging international monetary system, which can be accurately described as "Bretton Woods, reversed." 


\section{References}

Ball, Laurence and Niamh Sheridan (2003) "Does Inflation Targeting Matter?” NBER Working Paper No. 9577.

Benigno, Gianluca and Pierpaolo Benigno (2005) “Implementing International Monetary Cooperation through Inflation Targeting" unpublished.

Benigno, Gianluca and Pierpaolo Benigno (2006) “Designing Targeting Rules for International Monetary Policy Cooperation” Journal of Monetary Economics 53, 473-506.

Bernanke, Ben S., Thomas Laubach, Frederic S. Mishkin, and Adam S. Posen (1999) Inflation Targeting (Princeton: University Press).

Bernanke, Ben S. and Frederic S. Mishkin (1997) "Inflation Targeting: A New Framework for Monetary Policy?” Journal of Economic Perspectives 11(2), 97-116.

Calvo, Guillermo A., Alejandro Izquierdo, and Luis-Fernando Mejía (2004) "On the Empirics of Sudden Stops: The Relevance of Balance-Sheet Effects” NBER Working Paper No. 10,520.

Calvo, Guillermo A., Alejandro Izquierdo, and Ernesto Talvi (2006) "Phoenix Miracles in Emerging Markets: Recovering without Credit from Systematic Financial Crises” NBER Working Paper No. 12,101.

Calvo, Guillermo A. and Carmen M. Reinhart (2000) "Fear of Floating" NBER Working Paper No. 7993.

Eichengreen, Barry (1996) Globalizing Capital (Princeton: University Press).

Eichengreen, Barry, Poonam Gupta and Ashoka Mody (2006) "Sudden Stops and IMFSupported Programs" NBER Working Paper No. 12,235.

Frankel, Jeffrey A. and Eduardo A. Cavallo (2004) "Does Openness to Trade Make Countries More Vulnerable to Sudden Stops, or Less? Using Gravity to Establish Causality" NBER Working Paper No. 10,957.

Frankel, Jeffrey A. and Shang-Jin Wei (2004) "Managing Macroeconomic Crises" NBER Working Paper No. 10,907.

Goodfriend, Marvin (2003) "Inflation Targeting in the United States?" NBER Working Paper No. 9981.

Gopinath, Gita and Roberto Rigobon (2006) “Sticky Borders” NBER Working Paper No 12,095.

Hau, Harald (2002) "Real Exchange Rate Volatility and Economic Openness: Theory and Evidence” Journal of Money, Credit, and Banking 34(3), 611-630. 
Ho, Tai-Kuang and Jürgen von Hagen (2004) "Money Market Pressure and the Determinants of Banking Crises" CEPR Discussion Paper No 4651.

International Monetary Fund (2005) “Chapter IV: Does Inflation Targeting Work in Emerging Markets?” World Economic Outlook September.

Kroszner, Randall S., Luc Laeven, and Daniela Klingebiel (2006) "Banking Crises, Financial Dependence and Growth" CEPR Discussion Paper No 5623.

Levin, Andrew T., Fabio M. Natalucci and Jeremy M. Piger (2004) "The Macroeconomic Effects of Inflation Targeting” Federal Reserve Bank of St. Louis Review 86(4), 51-80.

Levy-Yeyati, Eduardo and Federico Sturzenegger (2003) "To Float or to Fix: Evidence on the Impact of Exchange Rate Regimes on Growth" American Economic Review 93(4), 1173-1193.

Mishkin, Frederic S. (2004) "Can Inflation Targeting Work in Emerging Market Countries?" NBER Working Paper No. 10,646.

Mishkin, Frederic S. and Klaus Schmidt-Hebbel (2001) "One Decade of Inflation Targeting in the World” NBER Working Paper No. 8397.

Obstfeld, Maurice and Kenneth S. Rogoff (1995) “The Mirage of Fixed Exchange Rates" Journal of Economic Perspectives 9(4), 73-96.

Obstfeld, Maurice and Kenneth S. Rogoff (2002) "Global Implications of Self-Oriented National Monetary Rules” The Quarterly Journal of Economics 117(2), 503-535.

Reinhart, Carmen M. and Kenneth S. Rogoff (2004) "The Modern History of Exchange Rate Arrangements: A Reinterpretation" The Quarterly Journal of Economics 119(1), 1-48.

Siklos, Pierre L. (1999) "Inflation-Target Design: Changing Inflation Performance and Persistence in Industrial Countries" Federal Reserve Bank of St. Louis Review March, 47-58.

Taylor, John B. (2001) "The Role of the Exchange Rate in Monetary Policy Rules" American Economic Review 91(2), 263-267.

Wyplosz, Charles (2006) "European Monetary Union: the dark sides of a major success" Economic Policy 46, 207-261. 
Table 1: Durability of Exchange Rate Regimes for Control Group Countries

Table 1a: Average Probability of Regime Change

\begin{tabular}{|l|c|c|}
\hline & All Observations & Excluding Small Countries \\
\hline Levy-Yeyati and Sturzenegger 3-regime & .27 annually & .27 annually \\
\hline Levy-Yeyati and Sturzenegger 5-regime & .32 annually & .33 annually \\
\hline Reinhart-Rogoff & .01 monthly & .01 monthly \\
\hline
\end{tabular}

Table 1b: Average Time Between Regime Changes

\begin{tabular}{|l|c|c|}
\hline & All Observations & Excluding Small Countries \\
\hline Levy-Yeyati and Sturzenegger 3-regime & 3.0 years & 2.9 years \\
\hline Levy-Yeyati and Sturzenegger 5-regime & 2.6 years & 2.5 years \\
\hline Reinhart-Rogoff & 51.8 months (4.3 years) & 58.2 months (4.9 years) \\
\hline
\end{tabular}

Table 1c: Spell-Weighted Average Time Between Regime Changes

\begin{tabular}{|l|c|c|}
\hline & All Observations & Excluding Small Countries \\
\hline Levy-Yeyati and Sturzenegger 3-regime & 6.3 years & 6.1 years \\
\hline Levy-Yeyati and Sturzenegger 5-regime & 6.0 years & 5.7 years \\
\hline Reinhart-Rogoff & 55.4 months (4.6 years) & 67.0 months (5.6 years) \\
\hline
\end{tabular}

Levy-Yeyati and Sturzenegger data set available from http://www.utdt.edu/ ely/Base_2005.zip

Reinhart-Rogoff data set available from http://www.publicpolicy.umd.edu/faculty/reinhart/monthly1.dta 
Table 2: Survivorship of Exchange Rate Regimes for Control Group Countries

Table 2a: Treating Multiple Regimes as Country-Specific

\begin{tabular}{|l|c|c|c|c|}
\hline & $\begin{array}{c}\text { After 2 } \\
\text { years }\end{array}$ & $\begin{array}{c}\text { After 4 } \\
\text { years }\end{array}$ & $\begin{array}{c}\text { After 6 } \\
\text { years }\end{array}$ & $\begin{array}{c}\text { After 8 } \\
\text { years }\end{array}$ \\
\hline Levy-Yeyati and Sturzenegger 3-regime & .71 & .42 & .27 & .13 \\
\hline Levy-Yeyati and Sturzenegger 3-regime, without small & .64 & .39 & .28 & .13 \\
\hline Levy-Yeyati and Sturzenegger 5-regime & .69 & .37 & .20 & .08 \\
\hline Levy-Yeyati and Sturzenegger 5-regime, without small & .61 & .34 & .20 & .07 \\
\hline Reinhart-Rogoff & .73 & .49 & .35 & .20 \\
\hline Reinhart-Rogoff, without small & .76 & .58 & .47 & .29 \\
\hline
\end{tabular}

Table 2b: Multiple Regimes Independently

\begin{tabular}{|l|c|c|c|c|}
\hline & $\begin{array}{c}\text { After 2 } \\
\text { years }\end{array}$ & $\begin{array}{c}\text { After 4 } \\
\text { years }\end{array}$ & $\begin{array}{c}\text { After 6 } \\
\text { years }\end{array}$ & $\begin{array}{c}\text { After 8 } \\
\text { years }\end{array}$ \\
\hline Levy-Yeyati and Sturzenegger 3-regime & .35 & .21 & .13 & .09 \\
\hline Levy-Yeyati and Sturzenegger 3-regime, without small & .32 & .20 & .12 & .08 \\
\hline Levy-Yeyati and Sturzenegger 5-regime & .25 & .16 & .10 & .07 \\
\hline Levy-Yeyati and Sturzenegger 5-regime, without small & .23 & .14 & .09 & .06 \\
\hline Reinhart-Rogoff & .64 & .40 & .28 & .19 \\
\hline Reinhart-Rogoff, without small & .65 & .45 & .37 & .25 \\
\hline
\end{tabular}

Table 2c: Allowing Each Country to have Starting Regime

\begin{tabular}{|l|c|c|c|c|}
\hline & $\begin{array}{c}\text { After 2 } \\
\text { years }\end{array}$ & $\begin{array}{c}\text { After 4 } \\
\text { years }\end{array}$ & $\begin{array}{c}\text { After 6 } \\
\text { years }\end{array}$ & $\begin{array}{c}\text { After 8 } \\
\text { years }\end{array}$ \\
\hline Levy-Yeyati and Sturzenegger 3-regime & .91 & .73 & .48 & .39 \\
\hline Levy-Yeyati and Sturzenegger 3-regime, without small & .88 & .71 & .50 & .38 \\
\hline Levy-Yeyati and Sturzenegger 5-regime & .91 & .72 & .47 & .38 \\
\hline Levy-Yeyati and Sturzenegger 5-regime, without small & .87 & .70 & .48 & .35 \\
\hline Reinhart-Rogoff & .72 & .56 & .41 & .26 \\
\hline Reinhart-Rogoff, without small & .73 & .63 & .53 & .33 \\
\hline
\end{tabular}

Levy-Yeyati and Sturzenegger data set available from http://www.utdt.edu/ ely/Base_2005.zip

Reinhart-Rogoff data set available from http://www.publicpolicy.umd.edu/faculty/reinhart/monthly1.dta 
Table 3: Features of International Monetary Systems

\begin{tabular}{|l|l|c|c|}
\hline & & Bretton Woods & Inflation Targeting \\
\hline 1 & Regime Durability & Low & High \\
\hline 2 & Exchange Rate Regime & Fixed & Floating \\
\hline 3 & Focus of Monetary Policy & International (at least in part) & Wholly Domestic \\
\hline 4 & Intermediate Target & Exchange Rate & None/Inflation Forecast \\
\hline 5 & Capital Mobility & Controlled & Relatively unrestricted \\
\hline 6 & $\begin{array}{l}\text { Capacity for Current } \\
\text { Account Imbalances }\end{array}$ & Limited & High \\
\hline 7 & System Design & Planned & Unplanned \\
\hline 8 & International Cooperation & Necessary & Not required \\
\hline 9 & Role of IMF & Key in principle & Small \\
\hline 10 & Role of Gold & Key in principle & Negligible \\
\hline 11 & Role of US as Center Country & Key in practice & Small \\
\hline 12 & Key Members & Essentially Large and Northern & OECD/LDCs, often small \\
\hline 13 & Central Banks & Dependent, Unaccountable & Independent, Accountable \\
\hline 14 & Transparency & Low & High \\
\hline 15 & Alignment with Academics & Low & High \\
\hline
\end{tabular}


Table 4: Exchange Rate Volatility in Inflation Targeting and Control Countries

\begin{tabular}{|c|c|c|c|c|c|c|}
\hline & \multicolumn{3}{|c|}{ Nominal } & \multicolumn{3}{|c|}{ Real } \\
\hline Volatility Interval: & 4 years & 8 years & $16 \mathrm{yrs}$ & 4 years & 8 years & 16 yrs \\
\hline Default & $\begin{array}{l}-.05 \\
(.05)\end{array}$ & $\begin{array}{l}-.14 \\
(.10)\end{array}$ & $\begin{array}{l}-.32^{*} \\
(.15)\end{array}$ & $\begin{array}{l}-.00 \\
(.01)\end{array}$ & $\begin{array}{l}-.01 \\
(.02)\end{array}$ & $\begin{array}{l}-.05 \\
(.03)\end{array}$ \\
\hline Without Time Effects & $\begin{array}{l}-.06 \\
(.05) \\
\end{array}$ & $\begin{array}{l}-.15 \\
(.10)\end{array}$ & & $\begin{array}{l}-.00 \\
(.01) \\
\end{array}$ & $\begin{array}{l}-.01 \\
(.02) \\
\end{array}$ & \\
\hline No Controls & $\begin{array}{l}-.10^{*} \\
(.04)\end{array}$ & $\begin{array}{l}-.19^{*} \\
(.08)\end{array}$ & $\begin{array}{c}-.40^{* *} \\
(.13)\end{array}$ & $\begin{array}{l}-.03^{*} \\
(.01)\end{array}$ & $\begin{array}{l}-.04 * \\
(.02)\end{array}$ & $\begin{array}{c}-.07^{* *} \\
(.02)\end{array}$ \\
\hline $\begin{array}{l}\text { Without Population or Current } \\
\text { Account }\end{array}$ & $\begin{array}{l}-.06 \\
(.05)\end{array}$ & $\begin{array}{l}-.11 \\
(.09)\end{array}$ & $\begin{array}{l}-.31^{*} \\
(.15)\end{array}$ & $\begin{array}{l}-.00 \\
(.02)\end{array}$ & $\begin{array}{l}-.01 \\
(.02)\end{array}$ & $\begin{array}{l}-.05 \\
(.03)\end{array}$ \\
\hline $\begin{array}{l}\text { Untransformed Openness } \\
\text { Measure }\end{array}$ & $\begin{array}{l}-.05 \\
(.05)\end{array}$ & $\begin{array}{l}-.13 \\
(.10)\end{array}$ & $\begin{aligned}-.33^{*} \\
(.16)\end{aligned}$ & $\begin{array}{l}-.00 \\
(.01)\end{array}$ & $\begin{array}{l}-.02 \\
(.02)\end{array}$ & $\begin{array}{l}-.05 \\
(.03)\end{array}$ \\
\hline Without $1.5 \sigma$ outliers & $\begin{array}{l}-.06 \\
(.05)\end{array}$ & $\begin{array}{l}-.15 \\
(.10)\end{array}$ & $\begin{array}{l}-.18^{*} \\
(.08)\end{array}$ & $\begin{array}{l}-.00 \\
(.01) \\
\end{array}$ & $\begin{array}{l}-.01 \\
(.02)\end{array}$ & $\begin{array}{l}-.03 \\
(.02)\end{array}$ \\
\hline $\begin{array}{l}\text { Quantile } \\
\text { Estimation }\end{array}$ & $\begin{array}{l}-.01 \\
(.01)\end{array}$ & $\begin{array}{l}-.04 \\
(.04)\end{array}$ & $\begin{array}{c}-.14^{* *} \\
(.05)\end{array}$ & $\begin{array}{c}.02 \\
(.01)\end{array}$ & $\begin{array}{l}.01 \\
(.03)\end{array}$ & $\begin{array}{l}-.04^{*} \\
(.02)\end{array}$ \\
\hline Without Small Countries & $\begin{array}{l}-.07 \\
(.05)\end{array}$ & $\begin{array}{l}-.17 \\
(.11)\end{array}$ & $\begin{array}{l}-.38^{*} \\
(.16)\end{array}$ & $\begin{array}{l}-.00 \\
(.01)\end{array}$ & $\begin{array}{l}-.02 \\
(.03)\end{array}$ & $\begin{array}{l}-.06 \\
(.03)\end{array}$ \\
\hline $\begin{array}{l}\text { Without Poor Countries (Real } \\
\text { GDP per capita }<\$ 5000 \text { ) }\end{array}$ & $\begin{array}{l}-.04 \\
(.04) \\
\end{array}$ & $\begin{array}{l}-.13 \\
(.09) \\
\end{array}$ & $\begin{aligned}-.27^{*} \\
(.12) \\
\end{aligned}$ & $\begin{array}{c}.00 \\
(.01) \\
\end{array}$ & $\begin{array}{l}-.01 \\
(.03) \\
\end{array}$ & $\begin{array}{l}-.04 \\
(.03)\end{array}$ \\
\hline $\begin{array}{l}\text { Without Countries that } \\
\text { switched to IT after } 2004\end{array}$ & $\begin{array}{l}-.04 \\
(.05)\end{array}$ & $\begin{array}{l}-.10 \\
(.10)\end{array}$ & $\begin{array}{l}-.26 \\
(.16)\end{array}$ & $\begin{array}{c}.01 \\
(.01)\end{array}$ & $\begin{array}{l}.00 \\
(.02)\end{array}$ & $\begin{array}{l}-.03 \\
(.03)\end{array}$ \\
\hline $\begin{array}{l}\text { Weighted by log } \\
\text { real GDP }\end{array}$ & $\begin{array}{c}-.05^{* *} \\
(.01)\end{array}$ & $\begin{array}{c}-.14^{* *} \\
(.02)\end{array}$ & $\begin{array}{c}-.32^{* *} \\
(.03)\end{array}$ & $\begin{array}{l}-.001 \\
(.003)\end{array}$ & $\begin{array}{c}-.011^{* *} \\
(.004)\end{array}$ & $\begin{array}{c}-.048^{* *} \\
(.005)\end{array}$ \\
\hline $\begin{array}{l}\text { Volatility of First-Differences of } \\
\text { Logs }\end{array}$ & $\begin{array}{l}-.002 \\
(.007)\end{array}$ & $\begin{array}{l}-.011 \\
(.012)\end{array}$ & $\begin{array}{l}-.019 \\
(.011)\end{array}$ & & & \\
\hline $\begin{array}{l}\text { Average Absolute First- } \\
\text { Difference of Logs }\end{array}$ & $\begin{array}{l}-.001 \\
(.004)\end{array}$ & $\begin{array}{l}-.004 \\
(.005)\end{array}$ & $\begin{array}{l}-.004 \\
(.004)\end{array}$ & & & \\
\hline
\end{tabular}

Figures tabulated are OLS coefficient estimates from regressions of exchange rate volatility on inflation targeting dummy. Controls not reported but included: a) current account (as percentage of GDP, mnemonic BN.CAB.XOKA.GD.ZS), b) natural logarithm of openness (trade as percentage of GDP, mnemonic NE.TRD.GNFS.ZS), c) log population (mnemonic SP.POP.TOTL), and d) log real PPP-adjusted GDP per capita (mnemonic NY.GDP.PCAP.PP.KD). All series are averages of annual series from World Development Indicators. Intercept and comprehensive time controls also included but not reported.

Regressand is effective exchange rate volatility, calculated as standard deviation of natural monthly logarithms.

Nominal rate is IFS line "neu" or "nec"; real rate is IFS line "rec."

Standard errors recorded in parentheses; * (**) denotes significance at the $.05(.01)$ level. 
$\underline{\text { Table 5: Sudden Stops in Inflation Targeting and Control Countries }}$

Table 5a: Calvo, Izquierdo, and Mejía (2004) sudden stops

\begin{tabular}{|r|c|c|c|c|}
\hline & Control Obs. & IT Obs. & Pre-IT Obs. & Total \\
\hline Tranquil Obs. & 64 & 93 & 119 & 276 \\
\hline Sudden Stops & 8 & 1 & 9 & 18 \\
\hline Total & 72 & 94 & 128 & 294 \\
\hline
\end{tabular}

Table 5b: Calvo, Izquierdo and Talvi (2006) systematic sudden stops

\begin{tabular}{|r|c|c|c|c|}
\hline & Control Obs. & IT Obs. & Pre-IT Obs. & Total \\
\hline Tranquil Obs. & 201 & 71 & 102 & 374 \\
\hline Sudden Stops & 9 & 1 & 6 & 16 \\
\hline Total & 210 & 72 & 108 & 390 \\
\hline
\end{tabular}

Table 5c: Eichengreen, Gupta and Mody (2006) sudden stops

\begin{tabular}{|r|c|c|c|c|}
\hline & Control Obs. & IT Obs. & Pre-IT Obs. & Total \\
\hline Tranquil Obs. & 132 & 58 & 99 & 289 \\
\hline Sudden Stops & 8 & 2 & 9 & 19 \\
\hline Total & 140 & 60 & 108 & 308 \\
\hline
\end{tabular}

Table 5d: Frankel and Cavallo (2004) sudden stops

\begin{tabular}{|r|c|c|c|c|}
\hline & Control Obs. & IT Obs. & Pre-IT Obs. & Total \\
\hline Tranquil Obs. & 400 & 127 & 148 & 675 \\
\hline Sudden Stops & 16 & 4 & 12 & 32 \\
\hline Total & 416 & 131 & 160 & 707 \\
\hline
\end{tabular}

Table 5e: Frankel and Wei (2004) sudden stops

\begin{tabular}{|r|c|c|c|c|}
\hline & Control Obs. & IT Obs. & Pre-IT Obs. & Total \\
\hline Tranquil Obs. & 435 & 47 & 105 & 587 \\
\hline Sudden Stops & 20 & 1 & 3 & 24 \\
\hline Total & 455 & 48 & 108 & 611 \\
\hline
\end{tabular}

Table 5f: Hypothesis Tests

\begin{tabular}{|l|c|c|c|c|c|}
\hline Sudden Stop Def. & CIM (2004) & CIT (2006) & EGM (2006) & FC (2004) & FW (2004) \\
\hline Control=IT & $2.9(.00)$ & $1.1(.25)$ & $.7(.48)$ & $.4(.67)$ & $.8(.45)$ \\
\hline IT $=$ pre-IT & $-2.1(.03)$ & $-1.4(.16)$ & $-1.3(.21)$ & $-1.7(.10)$ & $-.3(.80)$ \\
\hline
\end{tabular}

T-tests and associated p-values.

Note: "Pre-IT Obs." refer to the post-1989 but pre-IT observations for countries that adopted IT within the sample. 
Table 6: Key International Variables in Inflation Targeting and Control Countries

Table 6a: M2/Reserves

\begin{tabular}{|l|c|c|c|c|c|c|c|}
\hline Averages & $\mathbf{1 9 9 0 - 9 3}$ & $\mathbf{1 9 9 4 - 9 7}$ & $\mathbf{1 9 9 8 - 0 1}$ & $\mathbf{2 0 0 2 - 0 4}$ & $\mathbf{1 9 9 0 - 9 7}$ & $\mathbf{1 9 9 8 - 0 4}$ & $\mathbf{1 9 9 0 - 0 4}$ \\
\hline IT & 10.2 & 11.1 & 6.3 & 5.6 & 10.8 & 5.6 & 5.8 \\
\hline Control & 8.7 & 5.2 & 5.2 & 4.4 & 6.1 & 4.9 & 5.5 \\
\hline t-test| & .4 & 1.7 & .7 & .9 & 1.4 & .5 & .2 \\
\hline KS- P-value & .13 & $.02^{*}$ & .08 & .07 & $.03^{*}$ & .28 & .40 \\
\hline
\end{tabular}

Table 6b: Reserves in Months of Imports

\begin{tabular}{|l|c|c|c|c|c|c|c|}
\hline Averages & $\mathbf{1 9 9 0 - 9 3}$ & $\mathbf{1 9 9 4 - 9 7}$ & $\mathbf{1 9 9 8 - 0 1}$ & $\mathbf{2 0 0 2 - 0 4}$ & $\mathbf{1 9 9 0 - 9 7}$ & $\mathbf{1 9 9 8 - 0 4}$ & $\mathbf{1 9 9 0 - 0 4}$ \\
\hline IT & 2.9 & 3.1 & 3.6 & 4.2 & 3.1 & 4.1 & 4.1 \\
\hline Control & 3.5 & 3.3 & 3.8 & 5.0 & 3.3 & 4.3 & 3.8 \\
\hline $\mid$ t-test| & .8 & .3 & .4 & 1.1 & .3 & .4 & .5 \\
\hline KS P-value & .48 & .87 & .66 & .41 & .80 & .58 & .48 \\
\hline
\end{tabular}

Table 6c: Current Account, \%GDP

\begin{tabular}{|l|c|c|c|c|c|c|c|}
\hline Averages & $\mathbf{1 9 9 0 - 9 3}$ & $\mathbf{1 9 9 4 - 9 7}$ & $\mathbf{1 9 9 8 - 0 1}$ & $\mathbf{2 0 0 2 - 0 4}$ & $\mathbf{1 9 9 0 - 9 7}$ & $\mathbf{1 9 9 8 - 0 4}$ & $\mathbf{1 9 9 0 - 0 4}$ \\
\hline IT & -2.5 & -1.6 & .3 & .4 & -1.7 & .4 & .1 \\
\hline Control & -.3 & -1.8 & -1.3 & -.1 & -1.5 & -.7 & -.9 \\
\hline $\mid$ t-test $\mid$ & $2.7 *$ & .2 & 1.0 & .3 & .2 & .7 & .7 \\
\hline KS P-value & $.03 *$ & .82 & .63 & .62 & .74 & .19 & .75 \\
\hline
\end{tabular}

|t-test $\mid$ denotes the absolute value of a t-test for the null hypothesis of equal means between IT and control group countries. KS P-value denotes the probability for the Kolmogorov-Smirnov test for the null hypothesis of equality of distributions between IT and countries.

All series are averages of annual series from World Development Indicators: ratio of M2 to total reserves (FM.LBL.MQMY.IR.ZS); reserves in import months (FI.RES.TOTL.MO); and current account balance as \% GDP (BN.CAB.XOKA.GD.ZS). 
Table A1: Inflation Targeting Countries through 2004

\begin{tabular}{|l|r|r|r|}
\hline & Default Start Date & Conservative Start Date & Join EMU \\
\hline Australia & March, 1993 & September, 1994 & \\
\hline Brazil & June, 1999 & June, 1999 & \\
\hline Canada & February, 1991 & January, 1992 & \\
\hline Chile & January, 1991 & August, 1999 & \\
\hline Colombia & September, 1999 & October, 1999 & \\
\hline Czech Republic & January, 1998 & January, 1998 & \\
\hline Finland & February, 1993 & January, 1994 & January, 1999 \\
\hline Hungary & June, 2001 & August, 2001 & \\
\hline Iceland & March, 2001 & March, 2001 & \\
\hline Israel & January, 1992 & June, 1997 & \\
\hline Korea & April, 1998 & April, 1998 & \\
\hline Mexico & January, 1999 & January, 2001 & \\
\hline New Zealand & March, 1990 & March, 1990 & \\
\hline Norway & March, 2001 & March, 2001 & \\
\hline Peru & January, 2002 & January, 2002 & \\
\hline Philippines & January, 2002 & January, 2002 & \\
\hline Poland & September, 1998 & September, 1998 & \\
\hline South Africa & February, 2000 & February, 2000 & \\
\hline Spain & January, 1995 & January, 1995 & January, 1999 \\
\hline Sweden & January, 1993 & January, 1995 & \\
\hline Switzerland & January, 2000 & January, 2000 & \\
\hline Thailand & May, 2000 & May, 2000 & \\
\hline United Kingdom & October, 1992 & October, 1992 & \\
\hline & & & \\
\hline
\end{tabular}

After 2004:

\begin{tabular}{|l|r|}
\hline Indonesia & July, 2005 \\
\hline Romania & August, 2005 \\
\hline Slovak Republic & January, 2005 \\
\hline Turkey & January, 2006 \\
\hline
\end{tabular}

Histogram as of June 2006

\begin{tabular}{|c|c|c|c|c|c|c|c|}
\hline 0-2 yrs & 2-4 yrs & 4-6 yrs & 6-8 yrs & 8-10 yrs & $\mathbf{1 0 - 1 2}$ yrs & $\mathbf{1 2 - 1 4}$ yrs & $14+$ \\
\hline 4 & & 5 & 7 & 2 & & 3 & 4 \\
\hline
\end{tabular}


Table A2: Control Group Countries, Exchange Rate Regime Switches and Frameworks

\begin{tabular}{|c|c|c|c|}
\hline & \# LYS5 & \# RR & End-2004 Framework \\
\hline Algeria & 6 & 2 & Other \\
\hline Argentina & 3 & 2 & Other \\
\hline Belarus & 7 & 0 & Crawling Peg \\
\hline Bulgaria & 2 & 1 & Currency Board \\
\hline Cape Verde* & 5 & $\mathrm{n} / \mathrm{a}$ & Fixed Exchange Rate \\
\hline China & 0 & 2 & Fixed Exchange Rate \\
\hline Costa Rica* & 5 & 1 & Crawling Peg \\
\hline Croatia & 8 & 1 & Other \\
\hline Denmark & 0 & 1 & Fixed Exchange Rate \\
\hline Dominican Republic & 8 & 2 & Other \\
\hline Egypt & 7 & 1 & Monetary Target \\
\hline Estonia* & 0 & 1 & Currency Board \\
\hline Georgia & 1 & 2 & Other \\
\hline Guatemala & 7 & 1 & Other (transition to IT) \\
\hline Hong Kong, China & 0 & 0 & Currency Board \\
\hline Indonesia & 6 & 2 & Monetary Target, Now IT \\
\hline Iran & 5 & 2 & Monetary Target \\
\hline Jamaica* & 11 & 5 & Monetary Target \\
\hline Japan & 0 & 0 & Other \\
\hline Jordan & 5 & 2 & Fixed Exchange Rate \\
\hline Kazakhstan & 5 & 1 & Other \\
\hline Latvia* & 0 & 1 & Fixed Exchange Rate \\
\hline Lebanon & 3 & 2 & Fixed Exchange Rate \\
\hline Lithuania* & 2 & 1 & Currency Board \\
\hline Macao, China* & 0 & $\mathrm{n} / \mathrm{a}$ & $\mathrm{n} / \mathrm{a}$ \\
\hline Macedonia* & 5 & 2 & Fixed Exchange Rate \\
\hline Mauritius* & 7 & 1 & Monetary Target \\
\hline Morocco & 0 & 0 & Fixed Exchange Rate \\
\hline Paraguay & 11 & 2 & Other \\
\hline Romania & 9 & 2 & Other, Now IT \\
\hline Russia & 5 & 3 & Other \\
\hline Singapore & 9 & 1 & Other \\
\hline Slovakia & 8 & 3 & Now IT \\
\hline Slovenia* & 6 & 1 & Fixed Exchange Rate \\
\hline Syria & 0 & 0 & Fixed Exchange Rate \\
\hline Trinidad \& Tobago* & 9 & $\mathrm{n} / \mathrm{a}$ & Fixed Exchange Rate \\
\hline Tunisia & 11 & 0 & Crawling Peg \\
\hline Turkey & 6 & 2 & Now IT \\
\hline Ukraine & 6 & 4 & Fixed Exchange Rate \\
\hline Uruguay* & 5 & 3 & Monetary Target \\
\hline USA & 0 & 0 & Other \\
\hline Venezuela & 10 & 3 & Fixed Exchange Rate \\
\hline
\end{tabular}

* Indicates country with population greater than Iceland but less than New Zealand.

\# LYS Switches (\# RR switches) is the number of exchange rate regime shifts between 1990 and 2004 (2001) using Levy-Yeyati and Sturzenegger 5-regime (Reinhart-Rogoff) criteria.

Framework is as of December 31, 2004 from IMF's Classification of Exchange Rate Arrangements and Monetary Policy Frameworks. 


\section{Endnotes}

${ }^{1}$ In MonetaryProgramme of the NBS until the Year 2008 the National Bank of Slovakia defines its monetary policy as (p2): "Simultaneously, the NBS defines the conduct of its monetary policy as inflation targeting in the conditions of ERM II." (bold in original); http://www.nbs.sk/MPOL/MPROG/2008A.PDF.

${ }^{2} \mathrm{http} / / /$ www.rba.gov.au/PublicationsAndResearch/Bulletin/bu may99/bu 0599 2.pdf

${ }^{3}$ The dates are only significantly far apart in two cases: Chile (which maintained an exchange rate band along with its inflation target), Israel (which maintained a crawling exchange rate peg whose margins grew over time), and Mexico.

${ }^{4} \mathrm{http}: / /$ www.bankisrael.gov.il/abeng/1-5eng.htm

${ }^{5}$ For Canada and Norway, see http://www.bankofcanada.ca/en/backgrounders/bg-e2.html and http://www.norgesbank.no/english/monetary_policy/faq/\#interventions respectively. For Israel, see http://www.bis.org/publ/bppdf/bispap24p.pdf. The British intervention was to assist the G7 in supporting the euro in September 2000. See p 32 of Debt and Reserves Management Report 2006-07 available at http://www.hmtreasury.gov.uk/media/20C/37/bud06_dmo_282.pdf

${ }^{6} \mathrm{http}: / /$ www.bis.org/publ/bppdf/bispap24s.pdf. Despite this, Calvo and Reinhart (2000) characterize New Zealand as having a "fear of floating." Calvo and Reinhart focus on the difference between de facto and de jure behavior of exchange rates using non-structural techniques, and do not consider separately the (small number of) IT countries that are in their sample.

${ }^{7}$ A number of IT countries have reduced the importance of the exchange rate (as either an indicator or target of monetary policy) over time, including Chile, Israel, New Zealand. Alternatively, consider the countries pursuing inflation targeting according to the IMF's de facto monetary policy classifications. At the end of 2005 the inflation, there were: 2 countries with pegged exchange rates; 6 managed floaters; and 16 independent floaters. See http://www.imf.org/external/np/mfd/er/2005/1205.htm.

${ }^{8}$ Obstfeld and Rogoff $(1995$, p87) wrote "The number of long-lived fixed exchange rates still remaining in the world today is remarkably small ... The striking conclusion ... is that, aside from some small tourism economies, oil sheikdoms and highly dependent principalities, literally only a handful of countries in the world today have continuously maintained tightly fixed exchange rates against any currency for five years or more."

${ }^{9}$ Eichengreen (1996, p114) writes ".. it was only when the foreign-exchange markets opened for business in January 1959, with the major currencies fully convertible for current-account transactions, that the Bretton Woods System can be said to have come into full operation."

${ }^{10}$ The European Monetary System lasted from 1979 through the start of EMU in 1999, but only with a large number of realignments and crises, including the unceremonious withdrawal of the British pound and the Italian lira, surviving in the end only because the sterling and currency departures (and entries), and a remarkably wide fluctuation band of $+/-15 \%$.

${ }^{11}$ Indeed, it is worth pointing out that eleven countries hit by recent currency crises have switched to inflation targeting (Brazil, Czech Republic, Finland, Indonesia, Korea, Mexico, Philippines, Sweden, Thailand, Turkey, and the UK). Of the countries hit by major currency crises since 1990, only Argentina, Malaysia and Russia have not adopted inflation targeting.

${ }^{12}$ Both Finland and Spain used IT during their drives to enter EMU, and had 1998 inflation targets of 2\% which were slightly undershot.

${ }^{13}$ I use PWT6.1 data, for which 2000 is the last available year. The Philippines was the poorest IT country in 2000 with income per capita of $\$ 3400$; Peru was next at $\$ 4600$.

${ }^{14}$ Since EMU began half-way through the sample period, I do not include it or any EMU members in the control group. I also drop developing countries in currency unions, six of which would otherwise qualify for membership in the control group (Ecuador, El Salvador, Equatorial Guinea, Gabon, Panama, and Swaziland). None of the results below are substantially affected if the six LDCs are included in the control group.

${ }^{15}$ Iceland had just over 280,000 people in 2000, while New Zealand had over 3.8 million; the third-smallest country was Norway with almost 4.5 million.

${ }^{16}$ Thus far, four countries in the control group (Indonesia, Romania, Slovakia, and Turkey) have adopted IT in 2005-06.

${ }^{17}$ The IMF provides the framework as of December 31, 2004 in its "Classification of Exchange Rate Arrangements and Monetary Policy Frameworks"; see http://www.imf.org/external/np/mfd/er/2004/eng/1204.htm 
${ }^{18}$ In passing, exchange rate realignments (as e.g., occurred frequently during the EMS) are consistent with an unchanged exchange rate regime.

${ }^{19}$ The IMF reported de jure measures of exchange rate regimes until they switched in 1999 towards a more de facto based measure. Using this data, I find that there have been 45 fixes of exchange rate from 1990 onwards. Of these, 23 have now ended. Of the 22 that have not ended yet, there are three dollarizations (Ecuador, El Salvador, Timor Leste), and four European Currency Boards (Bulgaria, Estonia, Latvia, Lithuania). There are also twelve young (since 2000) fixes (Belarus, Iraq, Lebanon, Libya, Mauritania, Pakistan, Solomon Islands, Trinidad \& Tobago, Turkmenistan, Ukraine, Venezuela, Vietnam); these usually are associated with capital controls. This leaves three other countries (China, Guinea-Bissau, Morocco), all of whom also have strong controls.

${ }^{20}$ For instance there are missing gaps in LYS for important countries like China and the UK. Again: Reinhart and Rogoff cover the switches of Estonia and Latvia into current boards, whereas the LYS data begin after these dates.

${ }^{21}$ RR classify America as "freely floating" since February 1978 despite the change in operating procedures of October 1979. They also classify Canada as maintaining a "De facto crawling band that is narrower than or equal to +/-2\%" since June 1970, despite Canada's switch to IT.

${ }^{22}$ In their IMF Working Paper 02/155 "The Evolution of Exchange Rate Regimes Since 1990: Evidence from De Facto Policies" Andrea Bubula and Inci Ötker-Robe construct a monthly data set for the de facto exchange rate regimes of all IMF members between 1990 and 2001. Their classification delivers regime switches that are typically between LYS5 and RR; the mean number of year-end regime switches for BÖ-R/LYS5/RR are 2.2/4.8/1.5 while medians are 2/5/1. Eight countries had no regime switches according to BÖ-R, while there were ten and seven with LYS5 and RR respectively.

${ }^{23}$ The other countries currently in the same IMF classification are the Dominican Republic, Liberia, and Papua New Guinea.

${ }^{24}$ The maximal survivorship rate at eight years in Table 2 is .39 (for the LYS 3-way regime, allowing each country to have only the regime with which it started the sample. If we treat the nine IT countries that began at least eight years ago independently, this would be expected to happen with probability $(.39)^{9} \approx .0002$. Other survivorship assumptions or exchange rate classifications lower this number still further.

${ }^{25}$ Since IT regimes share a number of common features that differ from other monetary policies, I do not speculate on the reason(s) for this durability. This is a fruitful area for future research.

${ }^{26}$ Indeed, countries with fixed exchange rates (such as China) are more likely now to be viewed as suspiciously manipulating their rates than floaters, another contrast with the Bretton Woods period.

${ }^{27}$ Eichengreen $(1996$, p135) states "That this [Bretton Woods] system functioned at all is testimony to the international cooperation that operated in its support."

${ }^{28}$ Since my focus in this paper is on the international aspects of inflation targeting, I do not consider domestic issues like growth, inflation, and banking crises.

${ }^{29}$ Some observations are missing, since countries started IT well after the start of the sample. Thus e.g., Brazil does not contribute observations to either the group of countries before it starts IT in 1999.

${ }^{30}$ This makes country-specific fixed effects estimation infeasible, since no country experiences a regime change. Thus this test relies on cross-sectional variation.

${ }^{31}$ The data on the control variables are only available through the end of 2004, so that the regressand and regressor are sometimes not aligned perfectly. This is probably of negligible importance, since the regressor tend to add little explanatory power and are highly autoregressive in any case.

${ }^{32}$ For instance, developing countries in particular may find it difficult to adopt IT because of problems with: fiscal dominance, imperfect central bank independence, and weak financial systems.

${ }^{33}$ Parenthetically, I note in passing that no inflation targeter has ever, to the best of my knowledge, experienced a banking crisis. Ho and von Hagen (2004) review dates of banking crises from eight studies and create their own; none of the countries with long IT regimes (Australia, Canada, Chile, Israel, New Zealand, Sweden, and the UK) experienced a banking crisis during inflation targeting. Kroszner et al (2006) delivers the same message. 